\title{
Fishing With Sound: An Aesthetic Approach to Visualising Our Maritime Heritage
}

\author{
Chris Rowland \\ Duncan of Jordanstone College of Art \& Design \\ University of Dundee \\ Dundee, Scotland, UK \\ c.rowland@dundee.ac.uk
}

\section{INTRODUCTION}

As an island nation, the UK has a rich maritime heritage charting centuries of international trade and exploration. Evidence of this lies in abundance around the coastline in the form of historic shipwrecks. From 17th century remnants of Samuel Pepys navy off Goodwin Sands to bomb laden WWII liberty ships in the Thames estuary.

Unlike land based heritage sites, the majority of these underwater locations are virtually invisible to the public gaze. Their inaccessibility limits public perception of their importance; out of sight, out of mind. In rare cases, e.g. the Mary Rose, the wrecks are recovered and placed in purpose built museums alongside artefacts recovered from them. The enormous cost of archaeological recovery, preservation and exposition restricts this practice.

\section{3D VISUALISATION}

Recent improvements in multibeam sonar surveying by ADUS have resulted in opportunities to produce accurate 3D images of shipwrecks as they lie on the seabed from acoustic devices.

The author describes the development of novel and aesthetically focused 3D visualisation methods used to create high resolution, interactive Images of historic and environmentally significant shipwrecks. A number of case studies are used to illustrate the methods employed.

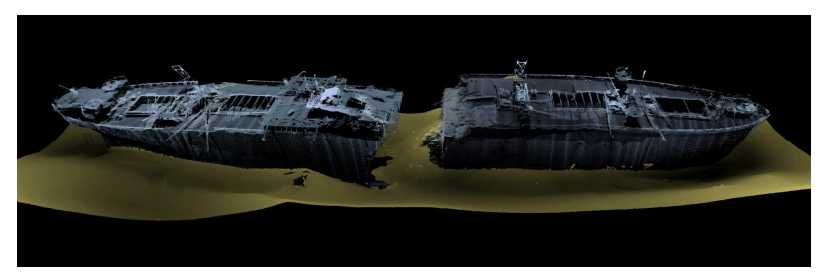

Figure 1: Wreck of the SS Richard Montgomery

\section{CASE STUDIES}

The wreck of the Royal Oak lies in Scapa Bay where the battleship was sunk at the start of WWII. The wreck has been leaking marine oil for decades and is laden with munitions. The Ministry of Defence has responsibility for extracting the oil and protecting the local environment which includes a bird sanctuary. To monitor the deterioration of the wreck, the ADUS team were invited to survey the wreck and provide accurate visualisation from the sonar data.

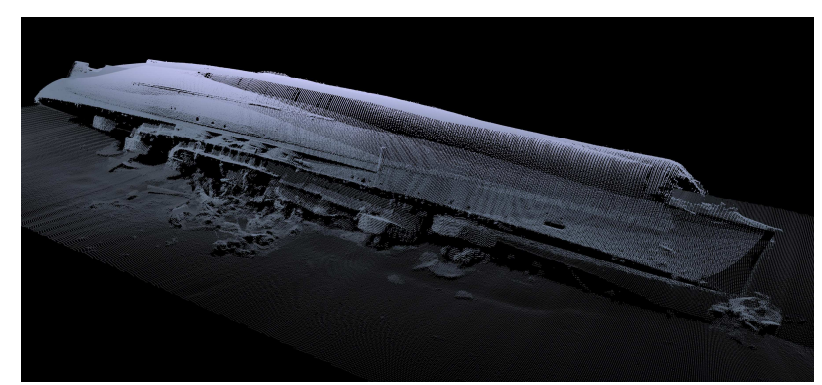

Figure 2: Visualisation of the Royal Oak

Similarly, the wreck of the US liberty ship: SS Richard Montgomery, lies in the Thames estuary off Sheerness, close t the shipping lane. It's cargo of munitions, 1.4 megatons of unexploded bombs, are still considered a serious threat to the environment. Other examples and further applications of the visualisation methods are discussed.

\section{REFERENCES}

Rowland, C. Anderson, J. (2010) WreckSlght: Visualising our Submerged Heritage. VAST2010, Eurographics , p39-45 ISBN 978-3-905674-29-3

Rowland, C. et al. (2008) High Resolution Wreck Surveys in Support of Salvage Operations, International Tug and Salvage, Nov/Dec 2008, p7172 